\title{
Chapter 15 \\ Improved Internship Practices as a Result of Collaborative Curriculum Design
}

\author{
Edward Akomaning
}

\section{Introduction}

The role of teachers in curriculum development, particularly in tertiary education, cannot be underestimated. Promising educational projects have failed because teachers were alienated from the educational reform at its commencement (Doyle \& Ponder, 1975). It is therefore imperative to involve teachers in the various phases of educational reforms. Because of their training, role and position in the educational system, they are in a better position to understand when and how subject matter should be taught (Fullan, 2007). However, in this day and age when the quality of tertiary graduates has become a subject of public discussion, it is equally important also to involve other stakeholders in curriculum development, so that the products that are designed are not perceived by other stakeholders as an imposition (Van den Akker, 2003) and therefore lack credibility during implementation. The shared responsibility becomes even more crucial when the development of the curriculum pertains to an internship programme, where educational institutions and industry need to cooperate closely to make it a successful learning experience for students. Thus, stakeholders' collaborative planning, in which the needs and interests of stakeholders are elicited, becomes paramount (Center for Careers, Life, and Service, 2014; Lewis, 2004).

Internship has become an important part of the curriculum of higher education (Beggs, Ross, \& Goodwin, 2008; Domask, 2007; Lam \& Ching, 2006; Walo, 2001), serving as an avenue through which the industry complements what is taught in the

\section{E. Akomaning $(\bowtie)$}

Institute for Educational Planning and Administration, University of Cape Coast,

Cape Coast, Ghana

e-mail: eakomaning@ucc.edu.gh 
classroom (Rothman, 2007). Internship as part of a formal education programme is an educational activity intended for students' acquisition of such competencies as are needed to obtain the required qualification at the end of their programme. In order to better provide high quality internship experiences, it is vital that internship stakeholders, particularly industry personnel and students, have comparable perceptions and expectations of the internship experience.

A previous study of the current situation of internship in the hospitality management sector in Ghana's polytechnics revealed that polytechnic-industry collaboration needs to be strengthened, interns need to have experience in all sectors of the industry, and curriculum materials need to be designed to guide student internships (Akomaning, Voogt, \& Pieters, 2011). This previous study further disclosed an episodic relationship between polytechnics and industries, lack of job rotation, lack of supervision of interns by teachers and industry-based supervisors, and the need for improvement in assigned work and student competencies. Other findings hint at the need for industry workers to cooperate with interns and the need for curriculum materials to be designed to streamline student internships. Therefore, the improvement in student internship programmes is an important aspect of the preparation of qualified staff for the sector and is a major concern in the curriculum reform in Ghana's polytechnics (Gervedink Nijhuis, Bakah, \& Akomaning, 2009). In order to address this need, the studies reported in this chapter adopted collaborative curriculum design (CCD) in teacher design teams as a strategy for collaboratively designing curriculum materials to improve student internships.

CCD is a bottom-up approach to curriculum improvement in which a group of teachers, teaching the same subjects or related subjects, work together on a regular basis with the ultimate goal of (re)designing and implementing (a part of) their common curriculum (Handelzalts, 2009). The underlying assumption for adopting the concept of CCD for our studies is that when teachers, who play very crucial roles when it comes to curriculum interpretation and implementation, are involved in curriculum design, they could be in a better position to incorporate materials that are relevant and practical for all stakeholders involved (i.e., students, teachers and industry personnel).

This chapter addresses two studies that aimed to contribute to an improved student internship curriculum for the hospitality management sector in Ghana's polytechnics by involvement of and collaboration among relevant stakeholders in the design of curriculum materials for internship. In the studies reported in this chapter, polytechnic teachers collaboratively designed curriculum materials to improve student internship in the hospitality industry, with input from students and industry personnel. The curriculum materials were implemented and the outcomes of the implementation examined. The underlying hypothesis was that CCD would lead to high quality curriculum products, culminating in smooth implementation and effective organisation of student internships. 


\section{Theoretical Underpinnings}

\section{Prerequisites for Implementation of a Renewed Internship Curriculum}

Internships have a long and noteworthy history in higher education (Beggs et al., 2008). Internship provides an opportunity and a learning scenario for students to experience, first-hand, professional practice activities that directly relate to the application of knowledge. Bakar, Harun, Yusof, and Tahir (2011) considered internship as an opportunity to integrate career-related experience into an education programme by participating in planned and supervised work. According to Clark and Whitelegg (1998), internship fosters "learning by doing", which in its turn reinforces the understanding of complex concepts and the development of complex skills. A successful internship requires conceptualising the internship situation more clearly as an authentic workplace learning environment (Blokhuis \& Nijhof, 2008) in which industry's contributions can be best organised to assist the learning required of the intern. Hasbullah and Sulaiman (2002) asserted that students' competencies improved remarkably after their experience in industry through the use of curriculum materials for student internship. The use of curriculum materials specifying what is to be learnt and who is responsible for what could create a better platform for internships to be better organised (Ko, 2008).

Internships also afford student training under both academic and practitioner supervision (Barber \& Bailey, 2015; Beggs et al., 2008). This supervision allows students to gain interpersonal skills with industry workers (Thiel \& Hartley, 1997). However, in order to ensure that the internship experience meets the needs of the industry, teacher and student, it is important to ensure that there are curriculum materials specifying their roles in the internship. In addition, articulating the responsibilities of interns and internship supervisors (educators and industry-based) prior to the internship is a key element in a successful internship (Beggs, Ross, \& Knapp, 2006; Rothman, 2007).

\section{Design Teams and Collaborative Curriculum Design}

A design team is described as a collaborative group working together to produce a unit of instruction or to create a product (Waddoups, Wentworth, \& Earle, 2004) that is implemented and evaluated (Handelzalts, 2009) in an educational institution's programme. It implies that in the design process teachers investigate challenges in their current instructional practice, (re-)design product(s), implement the product(s) and evaluate it. Collaboration in design teams contributes to enhancing teacher knowledge, skills and practices (Handelzalts, 2009; Simmie, 2007). The sense of security that comes from the support of colleagues in design teams results in greater 
willingness to experiment, try new things, and be more apt to consider continual development in curriculum reform (Hargreaves, 2003).

Participation in self-managed design teams, where members have the authority to make decisions and take actions to advance goals determined by the team, may intensify members' commitment to the team and foster collaboration among team members (Dee, Henkin, \& Singleton, 2006; Waddoups et al., 2004). Teacher collaboration in design teams, according to Little (1990) and Riordan (2001), denotes joint work, shared responsibility and the existence of high levels of trust, respect and mutuality. Design teams' activities are most often guided by a common goal. Attributes such as cooperation, collaboration, consensus and teamwork are crucial to the success of design teams, which not only result in a concrete product, but also culminate in professional learning (Deketelaere \& Kelchtermans, 1996; Fullan, 2007).

CCD in design teams is one such initiative, in which teachers get into teams to carry out activities that lead to both improvement in student learning (Havnes, 2009) and teacher professional development. Increasing levels of participation within a team are the key to how learning occurs (Blackwell, 2003). In fact, research has suggested that collaboration in curriculum design can potentially lead to several possible learning gains for teachers, such as increased content knowledge in a target domain (Kolodner et al., 2003; Rock \& Wilson, 2005; Voogt et al., 2011) and improvements in general process and collaboration skills (Guskey, 2000; Kolodner et al., 2003). CCD in design teams was used in the present studies to prepare curriculum materials for the student internship programme for hospitality management students. This approach promotes collaborative planning incorporating the interests of students, teachers and industry personnel (Lewis, 2004).

\section{Ensuring High Quality Curriculum Materials as a Result of Collaborative Design}

According to Kessels and Plomp (1999), the quality of educational programmes in terms of their influence is determined to a large extent by the "consistency" of the curriculum. Internal consistency refers to the logical sequencing of the various components of the curriculum. Internal consistency is reached through a "systematic approach" (Kessels \& Plomp, 1999), which implies the systematic design sequence of orientation, design, development, and evaluation. Denton, Kleist, and Surendra (2005) further asserted that the internal consistency of a curriculum could be improved by eliminating duplication or overlap of topics. External consistency, on the other hand, refers to the coherence of the perceptions of stakeholders (i.e., students, teachers and industry personnel) regarding the problem for which an intervention (e.g., collaborative design of curriculum materials) is needed and how it should be solved. External consistency is reached through a "relational approach", corresponding to the communicative paradigm (Kessels \& Plomp, 1999). It implies the involvement of stakeholders in the design and development process, thereby 
revealing their perceptions of the main goals of the process and of how they should be achieved.

Our studies, therefore, use CCD in design teams as a means to realise both the internal and external consistency of the curriculum materials, because teachers play a significant role in facilitating teaching and learning (Hattie, 2003) as well as being conversant with what goes on in industry through their training and experience (Heath, 2010). The composition of design teams and their ability to elicit suggestions from other stakeholders in the design of curriculum materials for student internship cannot be overemphasized if high quality work is to be ensured (cf. Kessels \& Plomp, 1999).

\section{Practicality of the Curriculum Materials in Renewed Internship}

Stakeholders' perceived attitude accounts for the successful use of a curriculum (Doyle \& Ponder, 1975), which is prompted by how its contents and components are systematically aligned (relevance and consistence) with the requirements of end users. According to Nieveen (2009), a key characteristic of high quality curriculum materials is that end users (stakeholders) consider them to be usable and largely well-suited to the developers' intentions. In this vein, practical use of the materials by stakeholders during internship would be guaranteed, and ultimately implementation would be facilitated and the intended objectives of the renewed internship would be achieved, with expected outcomes (Sackney, Mitchell, \& Walker, 2005).

\section{Effects on Students' Competencies and Assessment of Curriculum Materials}

The quality of curriculum materials should not rest simply on the relevance and consistency phase, but on its effects as a result of implementation. The main objective of training is to help interns gain knowledge, develop positive attitudes, and apply what they have learned to real-life practices (Wilson, Strutton, \& Farris, 2002). Internship can therefore nurture the student's correct work attitude and cooperation with others (Heppell, 2004). The curriculum materials would hence be considered effective if the intended objective is realised in interns' competencies and attitudes.

\section{Institutional Support for Renewed Internship}

Formalisation of the relationship between school and industry by a written contract specifying the tasks of the internship that correspond to the learning objectives as well as the provision of appropriate insurance are characteristics that foster 
successful internship (Youth Forum Jeunesse, 2009). An internship coordinator should be designated to provide both the intern and the business with information and also to intercede when problems arise (Cook, Parker, \& Pettijohn, 2004). Additionally, internship, as a form of career-related experience that complements what is learned in the classroom, builds upon the relationship that the educational institution has with employers and is most successful when the student, the department/polytechnic, and the employer all share responsibility for making it a valuable experience (Center for Careers, Life, and Service, 2014; Rothman, 2007).

\section{Resolution of Implementation Challenges}

A key component to making an internship programme stand out is job rotation. This allows interns to rotate among department functions to gain experience with a range of activities (Gillim, 2006). It is important for an intern to be continually and consistently evaluated from various points of view through periodical evaluations conducted each time the intern rotates into a different section.

Workplaces that make efforts to create positive working environments for interns could serve to increase not only the interns' effective commitment to the organisations, but also their long-term commitment to the occupation (Dixon, Cunningham, Sagas, Turner, \& Kent, 2005). These authors contended that interns should be treated with the same respect as any employee, as friendliness and helpfulness go a long way in affecting an intern's opinion of an organisation.

The assumption underlying our studies is that with the support of management, CCD contributes to curriculum improvement, and hence to the improvement of student internships and student learning. In order to ensure successful improvement of the curriculum, all key stakeholders must be involved (Van den Akker, 2003). Research on teacher teams indicates that change is more likely to be effective and enduring when those responsible for its implementation are included in a shared decision-making process (Scribner, Sawyer, Watson, \& Myers, 2007). The quality of working relationships among teachers is strongly related to the implementation of an educational innovation (Fullan, 2007). The crux of successful implementation of an educational programme is not losing sight of the context of the school.

The studies reported in this chapter were aimed at designing an improved student internship programme. The first study answered the question whether collaborative design teams contribute to an improved curriculum for student internship. The second study focused on the design of curriculum materials produced by the design teams and answered the question whether these materials contributed to a renewed student internship programme, according to the stakeholders involved. 


\section{Context of the Studies}

Polytechnics in Ghana are part of the tertiary education system. Unlike the university, polytechnic education is practically-oriented and career-focused, preparing its students to provide middle-level manpower as supervisors and managers equipped with competencies that make them readily employable (or able to set up their own businesses) in the various sectors of the Ghanaian economy. However, the link between polytechnics and industry is episodic (Effah, 2005). In Ghana, industries are under no obligation to draw up a training programme for potential interns. Moreover, there is no policy on industries being compelled to give feedback on interns to polytechnics, which runs counter to the dictates of structured internships (McManus \& Feinstein, 2008). Internship activities in the polytechnics are under the auspices of the Industrial Liaison Unit (ILU) in each polytechnic.

The department of Hotel Catering and Institutional Management (HCIM) has the responsibility is to train students to assume managerial or supervisory roles in the hospitality industry. The HCIM programme is a 3-year tertiary programme. Entrants into the programme are predominantly those who have successfully completed the Home Economics programme at their senior secondary school. Successful students graduate with a Higher National Diploma (HND) certificate in hospitality management. In order to adequately prepare students for the industry, internship is an integral component of the HCIM programme. Internships are carried out in two sessions throughout the 3-year programme. Each session spans a period of 3 months at the end of the academic year. In all, students are supposed to participate in at least 6 months of internship throughout the entire study period of 3 years. These internship periods are supposed to be supervised by both polytechnic educators and industry representatives.

\section{First Study}

This study sought to determine the effect of CCD in design teams on improved curriculum materials for the renewed student internship programme. The key research question framing this study was Does collaborative curriculum design in design teams contribute to an improved curriculum for student internship?

\section{Designing Curriculum}

Workshops were organised for stakeholders on the challenges identified in the context and needs study (Akomaning et al., 2011) and possible solutions to the challenges from stakeholders with the view of improving student internships. After that, two teams of teachers were formed to collaboratively design curriculum materials 
for student internships. Each team consisted of four teachers. One team developed materials for food production and food and beverage, and the other developed materials for accommodations and front office operation. The design of the curriculum materials took about 8 weeks.

The curriculum materials had the following components: objectives of student internship, content descriptions of the four core areas of the hospitality industry, practical activities the students had to carry out during student internship, job rotation during internship, assessment and student supervision from teachers and industry personnel. The main guidelines for designing a student internship curriculum, discussed in the introduction were applied in the design of the curriculum materials: the length of time of the internship, need for job rotation, support in achieving the expected objectives set for interns, installing industry supervision, and effective cooperation of supervisors with interns.

\section{Method}

\section{Design of the Study}

The study is a single-case design (Yin, 2003) in the context of the polytechnic and the case is the Department of HCIM at Tamale Polytechnic, with teachers, students and industry as units of analysis.

\section{Participants}

Eight teachers participated in two design teams. Three of them had previous experience in curriculum development. The Industrial Liaison Officer (ILO) participated because he is the kingpin regarding the organisation of internships and is the link between the polytechnic and industry. Fifteen industry representatives comprising 11 hotels and 4 hospitals were involved. A total of 661 st-year $(n=41)$ and 2 nd-year $(n=25)$ students took part in the workshops at the start of the curriculum design process. Fifty-three out of the 66 participated in the data collection after the new curriculum had been developed and implemented (number of students available at the time of administering the questionnaire). Of those 53, 23 students participated in the new internship programme implemented in 2009 (referred to as trained) and 30 students did not participate in the internship (referred to as untrained). 


\section{Instruments}

\section{Student Questionnaires}

Two questionnaires were administered to students immediately after the meetings. The second questionnaire, similar to the first, was administered 5 months later, immediately after the internship. The questionnaires consisted predominantly of closed-ended statements, with responses on a five-point Likert scale and few openended questions on year group, gender, place of first and second internships and duration of the internships.

\section{Teacher Questionnaires}

Two questionnaires were administered to teachers. The first was administered immediately after the workshops. The rationale was to elicit background information on teacher experience with curriculum activities and their competencies in this regard, which were addressed by open-ended questions. The closed-ended items were responded to using a five-point Likert scale. The second questionnaire was administered to teachers after students had returned from their internships and was similar to the first one with some additions about support for design teams, and about satisfaction with involvement of stakeholders. Open-ended questions included: institutional support for design teams, the role played by teachers during the internship, problems encountered, assessment criteria, type of training students experienced, competencies acquired during design team sessions, and change in teacher perceptions about design teams.

\section{Recorded Sessions}

Design team sessions were recorded and analysed to support data about teacher perceptions of CCD.

\section{ILO Interview}

The ILO was interviewed after the internship concerning his role and contribution to the internship. He also answered questions on role expectations in other polytechnic groupings regarding the organisation of the internship, on challenges facing the unit and suggestions for improvement. 


\section{Industry Personnel Questionnaire}

The questionnaire administered to hotel industry and hospital personnel was mainly closed-ended items using a five-point Likert scale for responses, with a five openended questions. The close-ended items focused on formalisation of links between polytechnic and industry, active involvement of teachers in student internships, teacher and industry supervision, making students write reports that form part of their assessment and industry personnel's reports on students' performance to the polytechnic. The open-ended questions centred on name and type of organisation, position of respondent, description of training given to students, departments served by student(s) and the impact of curriculum materials on student internship.

\section{Checklist and Researcher Logbook}

The checklist was used to collect data during visits to students in organisations by the researcher. The purpose was to know first-hand the interns' situation and to interact with personnel at the organisations concerning the interns' general behaviour.

\section{Main Findings}

Some considerable improvements in internship practices could be observed. The internship was perceived by the interns to be beneficial and interns' acquisition of competencies in the four main domains of the hospitality industry was significant. The first-year students improved remarkably in their competencies in food and beverage and accommodations operations whereas the second-year students improved in front office operation. In comparison with other departments in the hospitality industry, the most restrictive department for interns, particularly the first-year students, is the front office, because industry personnel are selective when it comes to assigning interns to this department. This might have accounted for the marked improvement in the competencies of second-year students.

This study examined how design teams that received input from students and industry representatives collaboratively designed curriculum materials to improve student internships in the Department of HCIM at Tamale Polytechnic. The teachers, having collaborated over a period of 8 weeks, were positive about the CCD in design teams, which resulted in marginal improvement in their collaborative skills as expressed in professional commitment, interdependence, mutual respect, healthy interpersonal relationship and participatory decision making. The study also revealed that involvement of the polytechnic, teachers and industry regarding student internship needed to be strengthened. 
The curriculum materials were a source of guidance for both students and industry personnel. Teachers' lack of active involvement in the internship was due to the polytechnic's inability to provide the required resources to complement the efforts of industry. Students and industry personnel were satisfied with the job performance of students, but not teachers.

With support from the polytechnic administration as well as the support from industry and students, the design teams' activities led to the design of the improved curriculum materials that were used in the 2009 student internship programme. Hitherto, there had been no such guide. Teachers were of the opinion that CCD in design team creates a platform for sharing experiences with colleagues in a collegial atmosphere, which confirms the suggestion from other studies (see other chapters in this volume) that CCD in design teams with support can promote teacher learning and the collaborative skills of teachers. The marginal change in teacher perceptions could be due in part to the short-term nature of their activities in design teams.

Teachers', students' and industry personnel's views on the polytechnic's support for student internship were that it was very minimal (provision of introductory letter and assessment form to students willing to enroll in internship), and that the polytechnic-industry relationship needed to be strengthened. Teacher supervision of students during internship was absent, but the industry contribution on the whole was commendable. Students and industry personnel were positive about industry supervision, which was partly attributable to the use of the curriculum materials.

Students' assessment of industry's contribution to interns' training was very encouraging. Interns were given the opportunity to serve in different sections of the industry, industry workers were friendly and prepared to assist in the training of interns. These indices of successful internship were the result of guidance (stakeholders' roles specified in curriculum materials), which is corroborated in the work by Crossley et al. (2007) and Beggs et al. (2008). The self-assessed competencies of students who embarked on an internship (trained) were higher than those who did not (untrained). Moreover, trained students and industry personnel were quite satisfied with their activities during internship. Paradoxically, industry personnel were more satisfied with interns' job performance during the internship than their teachers were.

Guided internship is paramount, especially in polytechnic education, whose mandate is to equip its students with hands-on experience, so that internship is not a peripheral programme, but core. The introduction of CCD in design teams, a bottom-up approach to curriculum development, is a new concept in the Ghanaian polytechnics, but holds great promise in bringing about some fundamental changes that could promote content knowledge as well as the collaborative skills of teachers, and could eventually assert the polytechnic's position as a tertiary institution where curricula is not imposed by an external body (Van den Akker, 2003). The tremendous contribution of tourism and the hospitality industry to the world's economy should encourage institutions of higher learning to encourage CCD in design teams, so as to design appropriate curriculum that serves the interests of all stakeholders. 


\section{Second Study}

The main research question framing the study is: Do the curriculum materials produced by the design teams contribute to a renewed student internship programme, according to the stakeholders involved?

\section{Designing Curriculum}

To draw out suggestions for the improvement of the internship programme, teachers, students and industry personnel were first informed about the existing problems with student internships in Ghana's polytechnics (Akomaning et al., 2011). After that, two teams of the HCIM teachers at Takoradi Polytechnic, eight in each group, were formed to collaboratively design curriculum materials for the student internship. One team developed resource materials in food production and food and beverage, while the other designed materials/resources for accommodations and front office operation. The curriculum materials had the following components: rationale specifying the distinctive roles of teachers, students and industry personnel, content description of the four core areas of the hospitality industry, practical activities the students had to carry out during internship, job rotation and meaningful jobs assigned during internship and student supervision from teachers and industry personnel. Copies of the final document were made and distributed to all stakeholders before the commencement of internships in 50 hotels. During the student internships, the Industrial Liaison Officer (ILO) and teachers were expected to supervise the students.

\section{Methods}

\section{Participants}

Sixteen out of 22 HCIM teachers participated in two design teams. Six of them had previous experience in curriculum development. The ILO participated in the study because he played a pivotal role in the organisation of internships and is the link between the polytechnic and industry. Fifty organisations where students were placed for their internship also took part in the study. A total of 165 first-year $(n=104)$ and second-year $(n=61)$ students took part in the workshops at the start of the intervention. One hundred and forty-three (students available at the time of administering the questionnaire) out of the 165 students participated in the data collection at the end of the design process. Of those 143, 89 and 54 were first- and second-year students, respectively. 


\section{Research Instrumentation}

\section{Student Instruments}

A focus group discussion (FGD) with students addressed suggestions for improvement of the internships. Two questionnaires were administered to students. The first was administered after the FGDs. It had two parts: the first part was based on year groups. The second part centred on student self-assessment of their competencies in the four core domains in the hospitality management programme. The questionnaires included predominantly closed-ended statements with responses on a fivepoint Likert scale and five open-ended questions. The second questionnaire, similar to the first, was administered immediately after the internship 6 months later. The open-ended questions focused on year group, place of first and second internships and duration. Others asked about the sections of industry where the student had trained, and a brief description of competencies acquired in the recent internship. The close-ended statements were similar to the first questionnaire except for additions related to employers' satisfaction with job performance and assessment of the curriculum materials.

\section{Teacher Questionnaires and Interview}

Two questionnaires were administered to teachers. The first was administered immediately after the workshops. The rationale was to elicit background information on teacher experience in curriculum design activities (open-ended questions) and the teachers' collaborative skills related to ensuring high quality design (closedended statements). In addition, both the teacher questionnaire and interview addressed the practical use of the curriculum. There were also statements on institutional support regarding the polytechnic's link with industry, prior contact with industry before students went to their internships and the polytechnic's inquiries about places for students for internship. Finally, there were an open-ended question and closed-ended statements addressing supervision of students during internship by teachers and industry-based supervisors.

\section{ILO Interview}

The ILO was interviewed before and after the internship concerning implementation of the internship, supervision, challenges, practical use of the curriculum materials on internship, teacher roles, and the polytechnic's contribution to the internship. 


\section{Industry Personnel Questionnaires and Interview}

Personnel at all of the 50 workplaces visited were given the curriculum materials and questionnaire at the start of the study. Forty-one out of the 50 responded to the questionnaire (82\%). Five were interviewed at the start of the study regarding challenges and suggestions for improvement in the student internship programme. The first questionnaire given to industry personnel was mainly a closed-ended five-point Likert scale type on the practical use of curriculum materials, with five open-ended questions. Industry personnel assessed students' competencies during the internship (second questionnaire, from students' logbooks on the use of curriculum materials) with a rating scale of 1-5 representing weak and outstanding, respectively, and a statement from the first questionnaire on whether employers are satisfied with students' job performance sought to address the research question. Formalisation of the polytechnic-industry link and whether the polytechnic made prior contacts with industry before students came to the internship while the polytechnic looked for places for students to practice were statements on institutional support for the internship programme. Administration of this instrument was done after personnel were briefed on the curriculum materials. Retrieval of the instrument was carried out by the interns after the internship.

\section{Checklist and Researcher Logbook}

This instrument (checklist) was used to collect data during visits by the researcher to students in the hotel industry. The purpose was to know first-hand the interns' situation and to interact with personnel at the organisations concerning the interns' general behaviour. Student assigned roles, industry training, working environment, industry supervision, teacher supervision, competencies expected and competencies achieved were the indices being investigated. In all, 89 interns were visited at 50 hotels. The researcher's logbook captured the initial arrangements for workshops for the ILO, teachers, students and industry representatives, and design process for the curriculum materials.

\section{Main Findings}

This study focused on collaborative design of curriculum materials by teacher teams, with input by students and industry representatives, which were used during student internship to address the challenges of implementing this programme. The teachers ensured high quality in terms of consistency, practicality and effectiveness in the design process for the curriculum materials, by their training and experience. Teachers, students and industry personnel concurred with the practical usefulness of the curriculum materials in the training of students. The subsequent outcomes of 
student self-assessed competencies and industry-based assessment appear to be commendable. Stakeholders acknowledge that the curriculum materials serve as a guide to students' training, providing knowledge to both industry personnel and students as to what roles are expected of them. Internship practices improved in the areas of supervision, workers cooperating with interns, job rotation, and work assigned to interns. However, other significant improvements, which include the duration of the internship, placement and participation of interns could be traced to the improvement in the polytechnic-industry link/relationship.

The collaboration among teachers, with input from students and industry personnel, in the design of the curriculum materials, and the support of the polytechnic had positive effects on the organisation of the internship programme, culminating in improved internship practices and student competencies. This study is comparable to that by Cecil, Fu, and Jones (2010), who contended that stakeholders were fairly satisfied with the curriculum designed to improve student competencies because stakeholders had their roles defined and the material was equally usable. Another study by Ko (2008), in which stakeholders' contribution to the hospitality internship curriculum gave rise to interns' satisfaction with the internships and the perception of the curriculum as practical and useful is consonant with the findings of this study. This research shows that teachers were also satisfied with the polytechnic's prior contacts with industry before students were sent out for internship, but students held a contrary view. Notably, the role of the teacher in the design and use of curriculum material, regardless of where it is applied, cannot be over-emphasised. If it will cost the polytechnic more funds than it can bear, the polytechnic can devise other alternative ways of ensuring some form of monitoring without necessarily visiting industry sites. Generally, there was improvement on the part of all stakeholders. However, the polytechnic should endeavour to enroll more teachers in the internship supervision team and should continue to improve its collaboration with industry.

\section{Overall Conclusions}

The student internship programme is a critical component of the HCIM programme of polytechnics in Ghana. However, it was unstructured and therefore was fraught with several implementation challenges such as lack of curriculum materials to guide the programme, sporadic link between the polytechnic and industry, and some students not being placed for internship, as well as some teachers not getting the opportunity to participate in internship supervision. It is refreshing to note that the outcomes of these studies suggest a marked improvement in internship practices.

Collaborative curriculum design (CCD) in design teams was adopted as an approach for the project in these studies. This approach gave teachers the opportunity to design curriculum materials to help guide the organisation of student internships with input from industry personnel and students. Besides the crafting of the 
curriculum materials, the approach created a platform for teachers to collaborate and to generate ideas, and thereby promoted teacher professional development.

Management support is paramount for the successful execution of student internships. Both studies recorded general improvements in internship practices; however, some of the students at Tamale (first study) could not do internships and teachers could not supervise students during internships. The same cannot be said about Takoradi Polytechnic (second study), where teachers were involved in supervision and all students had the opportunity to intern. The discrepancy could be due to the fact that the former had a student internship programme that was less structured and management support was minimal.

\section{Reflections}

\section{Importance of the Context and Needs Analysis}

The implementation challenges emerged out of the context and needs analysis study (Akomaning et al., 2011) that informed the industrial liaison officers, teachers, students and industry personnel (key stakeholders) of the hospitality management programme. Following this awareness creation, the stakeholders, particularly the teachers, expressed the need for well-thought-out curriculum documents to be designed to help streamline the student internship experience. The need to design curriculum documents therefore prompted the adoption of collaborative curriculum design in design teams as a bottom-up approach feasible for addressing the implementation challenges.

\section{Collaborative Curriculum Design: Necessary Conditions}

Capacity has been identified as one of the missing links in the organisation of student internship programmes in Ghana's polytechnics. In the context of student internships, the description of student internship was unstructured and faced with challenges. Hence, the expected mandated functions or roles of teachers, students and industry personnel were not efficiently and effectively executed. In view of this, the research sought to address the challenges by adopting collaborative curriculum design as a bottom-up approach to empowering teachers in the Departments of HCIM to design curriculum materials in order to support the activities of student internship. The functionality of collaborative curriculum design in design teams depends on whether the conditions for working in teams are in place and on how the management of the educational institutions lends support to their activities. 


\section{High Quality Curriculum Materials for Improved Internship Practices}

The materials had a clear-cut rationale indicating that hospitality industry staff should endeavour to guide students during internships by ensuring that students served in all the sections of the industry and assigning them to meaningful and challenging tasks with the intent of better preparing students to transition smoothly from school to work. The objectives of the student internships were made explicit; the content of the curriculum materials was departmentalised into four areas, taking account of the students' grade levels. A clear definition of the roles of stakeholders (students, teachers and industry personnel) was important in the materials.

The contributions made by other stakeholders (students and industry representatives) during the design of the curriculum materials and the systematic arrangement of the components of the curriculum documents by design teams led to appreciation and easy application of the documents during internship by these stakeholders. In this regard, the outcomes of this research were consonant with the study by Kessels and Plomp (1999) on ensuring curriculum quality through a "systematic relational approach" that attends to internal and external consistency. In the studies reported in this chapter, an explicit rationale in relation to a clear distinction between the expected roles of polytechnic teachers, industry representatives and students was important. Coherence between content, objectives, activities and assessment was also crucial for the internal consistency of the materials and improved internship practices.

\section{Ownership and Sustainability}

An additional aim of this research project was to ensure that after the design and implementation phases, the reform would continue in the educational institutions. Hence, the quest for active involvement by participants (students, teachers, industry personnel and management representatives) in the various stages of the project was paramount. By so doing, they would not perceive the reform as an imposition from outside, but would take pride in what they had been able to execute. Thus, ownership, a critical component of educational reform, would be internalised by stakeholders. Claiming the products as theirs would facilitate implementation, and plausible positive outcomes would encourage stakeholders to sustain and even improve on the implementation of the reform in practice.

Currently, the polytechnics in Ghana as tertiary educational institutions have not weaned themselves completely from a regulatory body such as NABPTEX, the institute coordinating activities in curriculum design and development in the polytechnics. If collaborative curriculum design in design teams is given the needed support from all fronts (management, teachers, students and industry personnel), the functionality of its operations would be mutually beneficial for the key 
stakeholders in particular and the nation in general. Finally, Ghana stands to benefit immensely if personnel for the tourism and hospitality industry are better prepared for their jobs. The issue of graduate unemployment, which is of grave concern to the nation, could be greatly minimised through renewed student internships, because in this way students would be equipped with the competencies needed for employment or setting up their own business enterprises.

\section{References}

Akomaning, E., Voogt, J. M., \& Pieters, J. M. (2011). Internship in vocational education and training: Stakeholders' perceptions of its organisation. Journal of Vocational and Training, 63(4), 575-592.

Bakar, M. J. A., Harun, R. J., Yusof, K., \& Tahir, I. M. (2011). Business and accounting students' perceptions on industrial internship program. Journal of Education and Vocational Research, 1(3), 72-79.

Barber, L. K., \& Bailey, S. F. (2015). Internship supervision resources for developing student employability. DeKalb, IL: Northern Illinois University.

Beggs, B., Ross, C. M., \& Goodwin, B. (2008). A comparison of student and practitioner perspectives of the travel and tourism internship. Journal of Hospitality, Leisure, Sport and Tourism Education, 7(1), 31-39.

Beggs, B. A., Ross, C. M., \& Knapp, J. S. (2006). Internships in leisure services: An analysis of student and practitioner perceptions and expectations. Schole, 21, 1-20.

Blackwell, P. (2003). Developing departments. In P. Blackwell \& P. Blackmore (Eds.), Towards strategic staff development in higher education (pp. 119-130). Buckingham, UK: SRHE/Open University Press.

Blokhuis, F. T. L., \& Nijhof, W. J. (2008). Evidence-based design of workplace learning. In W. J. Nijhof \& L. F. M. Nieuwenhuis (Eds.), The learning potential of the workplace (pp. 163-180). Rotterdam, The Netherlands: Sense Publishers.

Cecil, A. K., Fu, Y., \& Jones, E. (2010). Monitoring student success: A systemic model for hospitality and tourism education. International CHRIE Conference-Refereed Track. Paper 10.

Center for Careers, Life, and Service. (2014). Student internship handbook: A guide for students participating in a Grinnell college affiliated internship experience. Grinnell, IA: Center for Careers, Life, and Service.

Clark, G., \& Whitelegg, J. (1998). Maximising the benefits from work-based learning: The effectiveness of environmental audits. Journal of Geography in Higher Education, 22, 325-334.

Cook, S. J., Parker, R. S., \& Pettijohn, C. E. (2004). The perceptions of interns: A longitudinal case study. Journal of Education for Business, 79(3), 179-185.

Crossley, J. C., Jamieson, L. M., \& Brayley, R. E. (2007). Introduction to commercial recreation and tourism: An entrepreneurial approach (5th ed.). Champaign, IL: Sagamore Publishing.

Dee, J. R., Henkin, A. B., \& Singleton, C. A. (2006). Organizational commitment of teachers in urban schools: Examining the effects of team structures. Urban Education, 41, 603-627.

Deketelaere, A., \& Kelchtermans, G. (1996). Collaborative curriculum development: An encounter of different professional knowledge systems. Teachers and Teaching: Theory and Practice, 2(1), 71-85.

Denton, J. W., Kleist, V. F., \& Surendra, N. (2005). Curriculum and course design: A new approach using quality function deployment. Journal of Education for Business, 81(2), 111-117.

Dixon, M. A., Cunningham, G. B., Sagas, M., Turner, B. A., \& Kent, A. (2005). Challenge is key: An investigation of affective organizational commitment in undergraduate interns. Journal of Education for Business, 80(3), 172-180. 
Domask, J. J. (2007). Achieving goals in higher education: An experiential approach to sustainability studies. International Journal of Sustainability in Higher Education, 8(1), 53-68.

Doyle, W., \& Ponder, G. A. (1975). The practicality ethic in teacher decision-making. Interchange, $8(3), 1-12$.

Effah, P. (2005). A decade of polytechnic education in Ghana: An assessment of achievements and failures. Proceedings of the First Sunyani Polytechnic Lecture Series, 1, 17-29.

Fullan, M. (2007). The new meaning of educational change (4th ed.). New York: Teachers College Press.

Gervedink Nijhuis, C., Bakah, M. A. B., \& Akomaning, E. (2009). Leadership challenges involved in managing institutional and curriculum changes in polytechnics. In W. Kouwenhoven, G. Oduro, \& K. Nsiah-Gyabaah (Eds.), Trends in polytechnic education in Ghana (pp. 85-100). Amsterdam, The Netherlands: Vrije Universiteit.

Gillim, M. (2006). Putting the pieces together: Effective characteristics of an HR internship program (Senior Honors Theses, Paper 60). Eastern Michigan University.

Guskey, T. R. (2000). Evaluating professional development. Thousand Oaks, CA: Corwin Press.

Handelzalts, A. (2009). Collaborative curriculum development in teacher design teams (Doctoral dissertation). Enschede, The Netherlands: University of Twente.

Hargreaves, A. (2003). Teaching in the knowledge society. Education in the age of insecurity. New York: Teachers College Press.

Hasbullah, H., \& Sulaiman, S. (2002, August). Industrial internship programme at University Technology Petronas - A collaboration strategy that enhanced students' soft skills in the everchanging technology. A paper presented at International Conference on Engineering Education, Manchester, UK.

Hattie, J. (2003, October). Teachers make a difference: What is the research evidence? Paper presented at the Australian Council for Educational Research Annual Conference on Building Teacher Quality, Melbourne, Australia.

Havnes, A. (2009). Talk, planning and decision-making in interdisciplinary teacher teams: A case study. Teachers and Teaching, 15(1), 155-176.

Heath, R. R. (2010). Ensuring preservice teachers' readiness to teacher standard-based curricula. North Carolina Middle School Association Journal, 2(25), 1-9.

Heppell, M. (2004). How to be brilliant. London: Pearson-Prentice Hall.

Kessels, J., \& Plomp, T. (1999). A systematic and relational approach to obtaining curriculum consistency in corporate education. Journal of Curriculum Studies, 31(6), 679-709.

Ko, W. (2008). Training, satisfaction with internship programs, and confidence about future careers among hospitality students. Journal of Teaching in Travel \& Tourism, 7(4), 1-15.

Kolodner, J. L., Camp, P. J., Crismond, D., Fasse, B., Gray, J., Holbrook, J., et al. (2003). Problembased learning meets case-based reasoning in the middle-school science classroom: Putting learning by design (TM) into practice. Journal of the Learning Sciences, 12(4), 495-547.

Lam, T., \& Ching, L. (2006). An exploratory study of an internship program: The case of Hong Kong students. Hospital Management, 26, 336-351.

Lewis, A. (2004, December). Rationalising a tourism curriculum for sustainable tourism development in small Island States: A stakeholder perspective. Paper presented at a conference on Critical Issues in Tourism Education of the Association for Tourism in Higher Education, Missenden Abbey, Buckinghamshire, UK.

Little, J. W. (1990). The persistence of privacy: Autonomy and initiative in teachers' professional relations. Teachers College Record, 91(4), 509-536.

McManus, A., \& Feinstein, A. H. (2008). Internships and occupational socialization: What are students learning? Developments in Business Simulation and Experiential Learning, 35, 128-137.

Nieveen, N. (2009). Formative evaluation in educational design research. In T. Plomp \& N. Nieveen (Eds.), An introduction to educational design research (pp. 89-101). Enschede, The Netherlands: Axis Media-ontwerpers.

Riordan, G. (2001). Teachers working together. The Practising Administrator, 23(1), 6-10. 
Rock, T. C., \& Wilson, C. (2005). Improving teaching through lesson study. Teacher Education Quarterly, 32(1), 77-92.

Rothman, M. (2007). Lessons learned: Advice to employers from interns. Journal of Education for business, 52(3), 140-144.

Sackney, L., Mitchell, C., \& Walker, K. (2005). Building capacity for learning communities: A case study of fifteen successful schools. Paper presented at the American Education Research Association annual meeting.

Scribner, J. P., Sawyer, R. K., Watson, S. T., \& Myers, V. L. (2007). Teacher teams and distributed leadership: A study of group discourse and collaboration. Educational Administration Quarterly, 43(1), 67-100.

Simmie, G. M. (2007). Teacher design teams (TDTs) - building capacity for innovation, learning and curriculum implementation in the continuing professional development of in-career teachers. Irish Educational Studies, 26(2), 163-176.

Thiel, G. R., \& Hartley, N. T. (1997). Cooperative education: A natural synergy between business and academia. SAM Advanced Management Journal, 62(3), 19-24.

Van den Akker, J. J. H. (2003). Curriculum perspectives: An introduction. In J. J. H. Van den Akker, W. Kuiper, \& U. Hameyer (Eds.), Curriculum landscapes and trends (pp. 1-10). Dordrecht, The Netherlands: Kluwer Academic Publishers.

Voogt, J., Westbroek, H., Handelzalts, A., Walraven, A., McKenney, S., Pieters, J., et al. (2011). Teacher learning in collaborative curriculum design. Teaching and Teacher Education, 27, $1235-1244$.

Waddoups, G. L., Wentworth, N., \& Earle, R. (2004). Principles of technology integration and curriculum development: A faculty design team approach. Computers in the Schools, 21(1/2), $15-23$.

Walo, M. (2001). Assessing the contribution of internship in developing Australian tourism and hospitality students' management competencies. Asia-Pacific Journal of Cooperative Education, 2(1), 21-28.

Wilson, P. H., Strutton, D., \& Farris II, M. T. (2002). Investigating the perceptual aspect of sales training. The Journal of Personal Selling \& Sales Management, 22(2), 77-111.

Yin, R. K. (2003). Case study research: Design and methods (3rd ed.). Thousand Oaks, CA: Sage Publications.

Youth Forum Jeunesse. (2009). Opinion paper on internships. Adopted by the Council of Members/ Extraordinary General Assembly: Brussels, Belgium, 8-9 May 2009.

Open Access This chapter is licensed under the terms of the Creative Commons Attribution 4.0 International License (http://creativecommons.org/licenses/by/4.0/), which permits use, sharing, adaptation, distribution and reproduction in any medium or format, as long as you give appropriate credit to the original author(s) and the source, provide a link to the Creative Commons licence and indicate if changes were made.

The images or other third party material in this chapter are included in the chapter's Creative Commons licence, unless indicated otherwise in a credit line to the material. If material is not included in the chapter's Creative Commons licence and your intended use is not permitted by statutory regulation or exceeds the permitted use, you will need to obtain permission directly from the copyright holder.

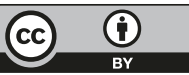

